\title{
Polarization and EIS studies to evaluate the effect of aluminum concentration on the corrosion behavior of SAC105 solder alloy
}

\author{
N. K. LiYANA ${ }^{1}$, M. A. FAZAL ${ }^{1,2, *}$, A. S. M. A. HASEeb ${ }^{1}$ \\ ${ }^{1}$ Department of Mechanical Engineering, University of Malaya, 50603 Kuala Lumpur, Malaysia \\ ${ }^{2}$ Department of Mechanical Engineering, University of Jeddah, Saudi Arabia
}

\begin{abstract}
This paper presents an investigation on corrosion behavior of $\mathrm{Sn}-1.0 \mathrm{Ag}-0.5 \mathrm{Cu}-\mathrm{XAl}(\mathrm{X}=0,0.1,0.5,1.0)$ by means of polarization and electrochemical impedance spectroscopy (EIS) measurements in $3.5 \mathrm{wt} . \% \mathrm{NaCl}$ solution. The results show that addition of aluminum into SAC105 shifts the corrosion current density and passivation current density towards more positive values. It is also found that with an increase in aluminum concentration in SAC105 solder alloy, the corrosion current density increases and polarization resistance decreases. This suggests that SAC105 with the highest concentration of Al has the lowest corrosion resistance. In this case, the corrosion behavior seems to be attributed to anodic dissolution of aluminum and Sn-matrix.
\end{abstract}

Keywords: corrosion; lead-free solders; EIS, polarization

\section{Introduction}

Previously, lead solder was popularly used in electronic industries because of its satisfactory properties including good soldering, low cost, adequate melting temperature range, proper physical, mechanical, metallurgical, and fatigue resistance properties [1]. However, lead is a poisonous metal which causes huge adverse effects for human health [2]. Therefore, lead has been banned in the industry, especially in electronics field [3]. Due to health and environmental concerns induced mainly by the lead content in conventional solders, the development of lead-free solders has become an important issue for material scientists. Good wettability, low melting point, low cost, adequate strength, good corrosion resistance and thermal fatigue, etc. are the characteristics that must be fulfilled by a new lead-free solder alloy in order to replace $\mathrm{Pb}$ containing solder alloys [4].

Quite a number of investigations have been done on the $\mathrm{Pb}$-free solders such as binary systems Sn-Ag, Sn-Zn, Sn-Cu, etc. [5-7] and ternary

*E-mail: fazal@uj.edu.sa systems such as $\mathrm{Sn}-\mathrm{Ag}-\mathrm{Cu}, \mathrm{Sn}-\mathrm{Ag}-\mathrm{Zn}, \mathrm{Sn}-\mathrm{Zn}-\mathrm{In}$, etc. [8]. Among these solders, ternary systems $\mathrm{Sn}-\mathrm{Ag}-\mathrm{Cu}$ with high $\mathrm{Ag}$ content such as $\mathrm{Sn}-4.0 \mathrm{Ag}-0.5 \mathrm{Cu}$ (SAC405) and $\mathrm{Sn}-3.0 \mathrm{Ag}-0.5 \mathrm{Cu}$ (SAC305) are considered to be promising replacements for the traditional $\mathrm{Sn}-\mathrm{Pb}$ solder alloys in microelectronic applications because of their satisfactory properties [9]. However, some issues arose in these alloys, such as increase in the relative cost of the products and drop impact reliability [10-15]. Therefore, Sn-Ag-Cu alloys with low $\mathrm{Ag}$ content, such as $\mathrm{Sn}-1.0 \mathrm{Ag}-0.5 \mathrm{Cu}$ (SAC105), have been considered as a solution to these problems $[13,16,17]$. However, the thermomechanical fatigue properties can be affected by reducing the $\mathrm{Ag}$ content $[18,19]$. In order to solve this problem, researchers have found a new alternative by adding fourth alloying element such as $\mathrm{Ni}, \mathrm{Zn}, \mathrm{In}, \mathrm{Al}, \mathrm{Bi}$, etc. into SAC105 alloys.

Among the various choices of alloying elements, Al has received attention of researchers [2022] because it is low cost and non-hazardous. Wei et al. [20] have investigated the effects of $\mathrm{Al}$ on the failure mechanism of the Sn-Ag-Zn eutectic solder. Both the ductility and tensile strength 
of Sn-3.7Ag-0.9Zn solder were decreased by the addition of 0.5 wt. $\%$ and 1 wt. $\%$ of Al. The effect of 0.1 wt. $\%$ and 0.2 wt. $\% \mathrm{Al}$ on microstructure and mechanical properties of $\mathrm{Sn}-1.0 \mathrm{Ag}-0.5 \mathrm{Cu}$ was investigated by Dhafer et al. [21]. They reported that the addition of $\mathrm{Al}$ resulted in larger and less-packed intermetallic compounds (IMCs), large primary $\beta$-Sn dendrites and shrunken interdendritic regions. Lee et al. [22] investigated the effect of $\mathrm{Al}$ addition on the wettability and drop impact reliability of $\mathrm{SnAgCu}$ solder. The addition of 0.005 wt.\% to 0.02 wt. $\% \mathrm{Al}$ into SAC105 resulted in decreased wetting time and increased wetting force. However, the amount of surface oxide was increased when $\mathrm{Al}$ content was over $0.1 \mathrm{wt} . \%$, hence, resulted in poor wetting properties.

Mohanty et al. [1] have studied the effect of Al on the electrochemical corrosion behavior of a fiveelement alloy. They reported that an increase in $\mathrm{Al}$ content decreased the corrosion current density and corrosion rate of the five-element alloy (Sn-8.5Zn$0.5 \mathrm{Ag}-\mathrm{XAl}-0.5 \mathrm{Ga}$ ). However, the corrosion potential value was shifted towards more noble value at higher $\mathrm{Al}$ content (1.5 wt.\%). In another study, Mohanty et al. [4] reported that their results were opposite to the previous study. With an increase in $\mathrm{Al}$ content, the corrosion current density and corrosion rate of Sn-8.5Zn-XAl-0.5Ga was increased, while the corrosion potential shifted towards more negative values.

Many researchers [20, 22] have investigated the influence of $\mathrm{Al}$ on the microstructure and mechanical properties of the solder alloys. However, there is a lack of studies about the effect of these elements on the corrosion behavior of three-element alloys, especially SAC105. Therefore, in this study, the effect of $\mathrm{Al}$ concentration on the corrosion behavior of SAC105 solder alloy in $3.5 \mathrm{wt} . \% \mathrm{NaCl}$ solution was investigated by polarization and electrochemical impedance spectroscopy (EIS) test.

\section{Experimental}

Potentiodynamic polarization test was conducted to obtain polarization curves in order to test the corrosion resistance of solder materials using Gamry G300 Potentiostat/Galvanostat (Gamry Instruments, Inc., USA). The solders used in the corrosion tests were obtained commercially Sn-1.0Ag-0.5Cu, Sn-1.0Ag-0.5Cu-0.1Al, $\mathrm{Sn}-1.0 \mathrm{Ag}-0.5 \mathrm{Cu}-0.5 \mathrm{Al}$ and $\mathrm{Sn}-1.0 \mathrm{Ag}-0.5 \mathrm{Cu}-$ 1.0Al. A 3.5 wt.\% $\mathrm{NaCl}$ solution was used as a corrosion medium to simulate sea water. After the solder materials were cut into blocks with specific dimensions $(1 \mathrm{~cm} \times 1 \mathrm{~cm} \times 1 \mathrm{~cm})$, a blind hole with a $1.6 \mathrm{~mm}$ diameter was drilled in the blocks surfaces for electrode connection. SiC paper grits $800,1000,1200$ and 1500 were used to polish the sample surfaces. Those were washed with distilled water to remove impurities and then cleaned with acetone.

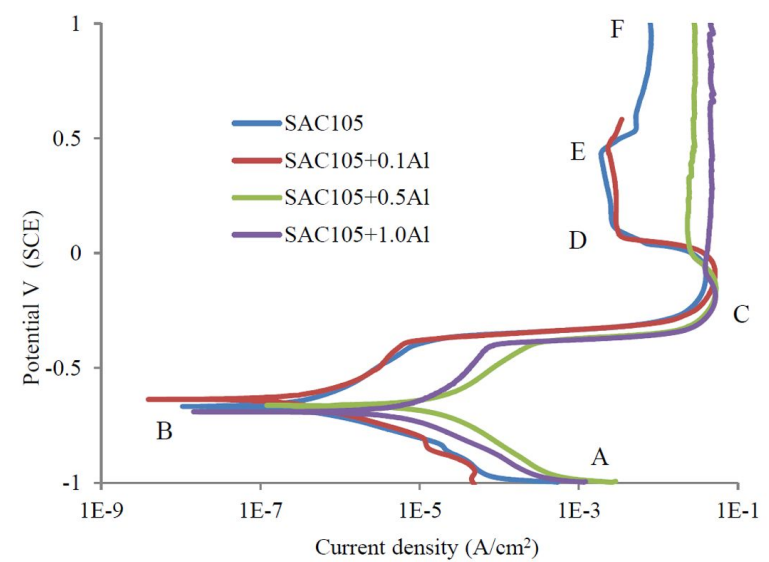

Fig. 1. Potentiodynamic polarization curves of SAC105, SAC105+0.1Al, SAC105+0.5Al and SAC105+1.0Al solder alloys in $3.5 \mathrm{wt} \% \mathrm{NaCl}$ solution.

Potentiodynamic polarization studies were carried out in a cell containing $3.5 \mathrm{wt} . \% \mathrm{NaCl}$ solution. A platinum wire was used as a counter electrode, and a reference electrode used in our study was a saturated calomel electrode (SCE). The solder alloy placed inside the cell served as a working electrode with the area of $1 \mathrm{~cm}^{2}$. Scanning of the potential was carried out from -1 to $+1 \mathrm{~V}$ at a scan rate of $1 \mathrm{mV} \mathrm{s}^{-1}$. The EIS measurement was done at the corrosion potential in a frequency range from $100 \mathrm{kHz}$ down to $0.01 \mathrm{~Hz}$. After the electrochemical corrosion test, the samples 
surfaces were characterized by scanning electron microscopy (SEM) equipped with energy dispersive $\mathrm{X}$-ray (EDX) analysis and X-ray Diffraction (XRD).

\section{Results and discussion}

\subsection{Potentiodynamic polarization curves}

The potential-current density profiles of the Sn$\mathrm{Ag}-\mathrm{Cu}-\mathrm{XAl}(\mathrm{X}=0,0.1,0.5,1.0)$ solders obtained by the potentiodynamic polarization studies carried out in 3.5 wt.\% $\mathrm{NaCl}$ solution are presented in Fig. 1. Since all corrosion tests were performed in an aerated $\mathrm{NaCl}$ solution the cathodic branch of polarization curves may be ascribed to the dissolved oxygen reduction reaction:

$$
\mathrm{O}_{2}+2 \mathrm{H}_{2} \mathrm{O}+4 \mathrm{e}^{-} \rightarrow 4 \mathrm{OH}^{-}
$$

The potential at point $\mathrm{B}$ is referred to as $\mathrm{E}_{\mathrm{corr}}$ (corrosion potential), where the extrapolated anodic and cathodic Tafel slopes intersect and the current becomes zero. Increasing the potential up to $\mathrm{E}_{\text {corr }}$ may induce dissolution of Al. The anodic reactions for dissolution of $\mathrm{Al}$ can occur by the following steps [1]:

$$
\begin{gathered}
\mathrm{Al}(\mathrm{s})+\mathrm{OH}^{-} \rightarrow \mathrm{Al}(\mathrm{OH})_{a d s}+\mathrm{e}^{-} \\
\mathrm{Al}(\mathrm{OH})_{a d s}+\mathrm{OH}^{-} \rightarrow \mathrm{Al}(\mathrm{OH})_{2 a d s}+\mathrm{e}^{-} \\
\mathrm{Al}(\mathrm{OH})_{2 a d s}+\mathrm{OH}^{-} \rightarrow \mathrm{Al}(\mathrm{OH})_{3 a d s}+\mathrm{e}^{-}
\end{gathered}
$$

The active dissolution of $\mathrm{Al}$ can be explained by the potential difference existing among the alloy elements. Table 1 shows that the electrode potential values of $\mathrm{Ag}, \mathrm{Cu}$ and $\mathrm{Sn}$ are much higher compared with that of Al. Thus, $\mathrm{Al}$ has been considered as the most active among these metals. As a result, $\mathrm{Al}$ acts as an anode in the alloy and, therefore, more easily dissolves in corrosive conditions.

$\mathrm{Al}(\mathrm{OH})_{3}$ production and deposition causes $\mathrm{Al}$ depletion. The active dissolution of $\mathrm{Al}$ continues with increasing potential until the hydroxide $\left(\mathrm{OH}^{-}\right)$concentration reaches a critical value and supersaturates the surface of the alloy at point $\mathrm{C}$.
The surface of the corroded samples covers by the insoluble hydroxide and creates a plateau region (DE) where the current density is found to be independent of potential. It should be noted that $\mathrm{Al}$ is the minor element in SAC105, so it is quickly depleted or blocked by $\mathrm{Al}(\mathrm{OH})_{3}$ on the surface. Thus Sn, as the second most active material after $\mathrm{Al}$ in this system, can be dissolved to $\mathrm{Sn}$ (II) species $[23,24]$ according to the reactions displayed below:

$$
\begin{gathered}
2 \mathrm{OH}^{-}+\mathrm{Sn} \rightarrow \mathrm{Sn}(\mathrm{OH})_{2}+2 \mathrm{e}^{-} \\
\mathrm{Sn}(\mathrm{OH})_{2} \rightarrow \mathrm{SnO}+\mathrm{H}_{2} \mathrm{O}
\end{gathered}
$$

The electrochemical data extracted from these curves are summarized in Table 2. It is seen that the SAC105 solder alloy exhibits the corrosion potential of $-668 \mathrm{mV}$ (SCE). With the addition of $0.1 \mathrm{wt} \% \mathrm{Al}$, the corrosion potential increases to $-637 \mathrm{mV}$ (SCE). However, as $0.5 \mathrm{wt} . \%$ and 1.0 wt.\% $\mathrm{Al}$ is added to the SAC105 solder alloy, the corrosion potential of the solder decreases to $-669 \mathrm{mV}$ (SCE) and $-692 \mathrm{mV}$ (SCE), respectively.

The corrosion-current density $I_{\text {corr }}$ is determined at the intersection of the Tafel lines which represent the corrosion rate of the system. From Fig. 1, it is seen that the shapes of the polarization curves for SAC105 and SAC105+ 0.1 Al solder alloys are almost similar and there is no significant difference of corrosion rate between these two alloys. The corrosion current density of SAC105 solder alloy is $0.451 \times 10^{-3} \mathrm{~mA} / \mathrm{cm}^{2}$, which is slightly lower than that of $0.526 \times 10^{-3} \mathrm{~mA} / \mathrm{cm}^{2}$ for SAC105+ 0.1 Al solder alloy. However, the addition of $0.5 \mathrm{wt} . \%$ and $1.0 \mathrm{wt} . \% \mathrm{Al}$ into SAC105 solder alloy shifts the corrosion current density to more positive values, which indicates an increase in corrosion rate. The corrosion current densities of SAC105 + 0.5Al and SAC105+1.0Al solder alloys are $11.1 \times 10^{-3}$ and $11.6 \times 10^{-3} \mathrm{~mA} / \mathrm{cm}^{2}$, respectively. Therefore, we can conclude that the addition of $\mathrm{Al}$ tends to decrease the corrosion resistance of the solder. These results are in accordance with that obtained by Mohanty et al. [1] when they investigated the effect of $\mathrm{Al}$ concentration on the 
Table 1. Electrode potential of solder elements.

\begin{tabular}{lcc}
\hline Element & Reaction & Electrode potential [V] \\
\hline \hline Silver & $\mathrm{Ag}^{2+}+\mathrm{e}^{-}=\mathrm{Ag}$ & +0.7996 \\
& $\mathrm{Cu}^{+}+\mathrm{e}^{-}=\mathrm{Cu}$ & +0.5210 \\
Copper & $\mathrm{Cu}^{2+}+2 \mathrm{e}^{-}=\mathrm{Cu}$ & +0.3419 \\
Tin & $\mathrm{Sn}^{2+}+2 \mathrm{e}^{-}=\mathrm{Sn}$ & -0.1375 \\
Aluminum & $\mathrm{Al}^{3+}+3 \mathrm{e}^{-}=\mathrm{Al}$ & -1.6600 \\
\hline
\end{tabular}

corrosion behavior of Sn-Zn-Al-Ga alloy. Mohanty et al. [1] reported that the corrosion current density and corrosion rate of $\mathrm{Sn}-8.5 \mathrm{Zn}-\mathrm{XAl}-0.5 \mathrm{Ga}$ increased significantly with an increase in $\mathrm{Al}$ content. At potential more positive than $\mathrm{B}$, corrosion rate increases and reaches a maximum at the passivation potential, $\mathrm{C}$, which is presented by symbol, $\mathrm{E}_{\text {pass }}$ and critical current density defined by symbol $\mathrm{I}_{\mathrm{cc}}$. At the passivation potential, the transition from active dissolution occurs as the solid species (oxide/hydroxide of $\mathrm{Al}$ and $\mathrm{Sn}$ ) become more stable than the parent metal ion [2]. The surface of the electrode is covered by these oxide/hydroxides, thereby decreasing the current density with further increment in potential to point D (Fig. 1). The current density observed in the passive region $\mathrm{DE}$ in Fig. 1 is referred to as the passivation current density $\left(\mathrm{I}_{\text {pass }}\right)$.

From Table 2, it is seen that SAC105 solder exhibits the smallest critical current density $\left(39.8 \mathrm{~mA} / \mathrm{cm}^{2}\right)$ and passivation current density $\left(2.55 \mathrm{~mA} / \mathrm{cm}^{2}\right)$. The values of current density increase as Al is added into SAC105 solder. However, the current density is found to be the lowest for $0.1 \mathrm{wt} . \% \mathrm{Al}$ in comparison to other alloys containing $\mathrm{Al}$, thus indicating the stability of the passive film formed on the surface. Al content of 1.0 wt.\% causes an increase in the passivation current density, thereby destabilizing the passive film which results in a higher rate of corrosion of the alloy. These results are in accordance with that obtained by Mohanty et al. [1]. They reported that solder with the lowest $\mathrm{Al}$ content has the lowest current density.

Further increase in the potential beyond $\mathrm{E}$ causes a sharp increase in the current, which indicates the transpassive region which might be due to the breakdown of the passive film by incorporation of $\mathrm{Cl}^{-}$anion into the oxide layer, leading to localized corrosion. Previous study [25] reported that the film was mechanically broken due to the penetration of chloride ions into the oxide film and forming a solid metal chloride. The overall view from Fig. 1 shows that the addition of Al shifted the corrosion current density and passivation current density towards more positive values. This suggests that SAC105 + 1.0Al solder alloy has the lowest corrosion resistance. Higher content of $\mathrm{Al}$ in the $\mathrm{Sn}-1.0 \mathrm{Ag}-0.5 \mathrm{Cu}-\mathrm{XAl}$ alloy enhances corrosion. These changes are also reflected in the corrosion rate as shown in Table 2.

\subsection{Corrosion rate}

The corrosion rate was obtained by Tafel fit using Gamry Echem Analyst DC105 software and the data are listed in Table 2. From Table 2, it is seen that SAC105 solder alloy shows the lowest corrosion rate, $0.07 \mathrm{mpy}$. When $0.1 \mathrm{wt} \%$ of Al was added, the corrosion rate was slightly increased to 0.08 mpy. Corrosion rate of SAC105 solder alloy kept increasing to $1.44 \mathrm{mpy}$ and $1.49 \mathrm{mpy}$ when 0.5 wt. $\%$ and 1.0 wt. $\%$ Al were added, respectively. As a result, it can be concluded that SAC105 + 1.0Al solder alloy deteriorates and corrodes more rapidly with the low corrosion resistance and the highest corrosion rate.

\subsection{Corrosion products}

The SEM micrograph in Fig. 2a shows the formation of needle like corrosion products in SAC105 solder alloy. However, upon addition of aluminum, the size of the corrosion products seems to be smaller (Fig. 2b and Fig. 2c). 
Table 2. Potentiodynamic polarization parameters for SAC105, SAC105 + 0.1Al, SAC105 + 0.5Al and $\mathrm{SAC} 105+1.0 \mathrm{Al}$ solder alloys in $3.5 \mathrm{wt} . \% \mathrm{NaCl}$ solution.

\begin{tabular}{cccccccc}
\hline Materials & $\begin{array}{c}\mathrm{E}_{\text {corr }} \\
{[\mathrm{mV}]}\end{array}$ & $\begin{array}{c}\mathrm{I}_{\text {corr }} \\
{\left[\mathrm{mA} / \mathrm{cm}^{2}\right]}\end{array}$ & $\begin{array}{c}\mathrm{I}_{\mathrm{cc}} \\
{\left[\mathrm{mA} / \mathrm{cm}^{2}\right]}\end{array}$ & $\begin{array}{c}\mathrm{I}_{\text {pass }} \\
{\left[\mathrm{mA} / \mathrm{cm}^{2}\right]}\end{array}$ & $\begin{array}{c}\mathrm{E}_{\text {pass }} \\
{[\mathrm{mV}]}\end{array}$ & $\begin{array}{c}\Delta \mathrm{E} \\
{[\mathrm{mV}]}\end{array}$ & $\begin{array}{c}\text { Corrosion } \\
\text { rate }[\mathrm{mpy}]\end{array}$ \\
\hline \hline $\mathrm{SAC} 105$ & -668 & $0.451 \times 10^{-3}$ & 39.8 & 2.55 & -120.6 & 285.3 & 0.07 \\
$\mathrm{SAC} 105+0.1 \mathrm{Al}$ & -637 & $0.526 \times 10^{-3}$ & 51.3 & 2.98 & -110.8 & 347.6 & 0.08 \\
$\mathrm{SAC} 105+0.5 \mathrm{Al}$ & -669 & $11.100 \times 10^{-3}$ & 52.1 & 24.30 & -134.6 & - & 1.44 \\
$\mathrm{SAC} 105+1.0 \mathrm{Al}$ & -692 & $11.600 \times 10^{-3}$ & 52.0 & 38.80 & -158.5 & - & 1.49 \\
\hline
\end{tabular}

Samples which were potentiodynamically treated were subsequently subjected to X-ray diffraction (XRD) analysis as shown in Fig. 3. The XRD patterns reveal the presence of $\mathrm{Sn}_{3} \mathrm{O}(\mathrm{OH})_{2} \mathrm{Cl}_{2}$ (ICDD 00-039-0314), SnO (ICDD 98-006-019) and $\mathrm{SnO}_{2}$ (ICDD 98-000-9178) on the exposed surface of $\mathrm{SAC} 105 . \mathrm{Al}(\mathrm{OH})_{3}$ (ICDD 98-000-6162) and $\mathrm{Al}_{2} \mathrm{O}_{3}$ (ICDD 00-010-0173) were detected on the surfaces of Al-containing solder alloys.

From the XRD analysis in Fig. 3, it is seen that $\mathrm{Sn}_{3} \mathrm{O}(\mathrm{OH})_{2} \mathrm{Cl}_{2}$ was undetectable when $\mathrm{Al}$ was added into SAC105 alloy. Instead, $\mathrm{Al}(\mathrm{OH})_{3}$ and $\mathrm{Al}_{2} \mathrm{O}_{3}$ appear to be formed on the surfaces of SAC105 + 0.1Al, SAC105+0.5Al and SAC105 + 1.0Al solder alloys. These results are in accordance with the previous study conducted by Mohanty et al. [1] when they studied the effect of $\mathrm{Al}$ on the electrochemical corrosion behavior of $\mathrm{Pb}$ free $\mathrm{Sn}-8.5 \mathrm{Zn}-0.5 \mathrm{Ag}-\mathrm{XAl}-0.5 \mathrm{Ga}$ solder in 3.5 wt. $\% \mathrm{NaCl}$ solution. They reported that considerable aluminum segregation towards the surface occurred, predominantly as $\mathrm{Al}_{2} \mathrm{O}_{3} / \mathrm{Al}(\mathrm{OH})_{3}$, with an increase in $\mathrm{Al}$ content to $1.5 \mathrm{wt} \%$ in the fiveelement solder.

\subsection{Electrochemical impedance spec- troscopy (EIS)}

Fig. 4 displays the Nyquist plots for SAC105, SAC105 + 0.1Al, SAC105 + 0.5Al and SAC105 + 1.0Al solder alloys in $3.5 \mathrm{wt} \%$ $\mathrm{NaCl}$ solution. As can be seen, the response of the system in the Nyquist complex plane is a semicircle arc for all materials whose diameter decreases with the addition of Al. The diameter of the Nyquist semicircle corresponds to the corrosion resistance. It is important to remark that the highest semicircle arc corresponds to the best electrochemical corrosion behavior. In Fig. 4, it is seen that the loop diameter of SAC105 solder alloy is the highest. As Al was added into SAC105 alloy, the loop diameter decreased, which indicates the increased corrosion rate and thus, the reduction of corrosion resistance with the addition of Al. This observation permits to conclude that the SAC105 solder alloy has the best corrosion resistance as compared to others alloy.

Fig. 5 shows the impedance spectra, presented as Bode plots, for SAC105, SAC105 + 0.1Al, $\mathrm{SAC} 105+0.5 \mathrm{Al}$ and $\mathrm{SAC} 105+1.0 \mathrm{Al}$ solder alloys in 3.5 wt.\% $\mathrm{NaCl}$ solution. It is well-known that the corrosion resistance of solder alloys can be determined by $\log |\mathrm{Z}|$ (Fig. 5a) and phase angle $\theta_{\max }$ (Fig. 5b) versus log frequency. Higher log $|\mathrm{Z}|$ and higher $\theta_{\max }$ represent better corrosion resistance. In the lower frequency region of the Bode plots (Fig. 5a), the $\log |\mathrm{Z}|$ tends to decrease with the addition of $\mathrm{Al}$ and it has been tabulated in Table 3 .

It can be seen from Fig. 5 that the SAC105 solder alloy exhibits the highest magnitude of impedance, $4229 \Omega \cdot \mathrm{cm}^{2}$, and highest $\theta_{\max }$, $-77.28^{\circ}$, indicating the highest corrosion resistance which is attributed to the formation of comparatively more adherent and protective oxide film on the surface. $\log |Z|$ and $\theta_{\max }$ tend to decrease with the addition of $\mathrm{Al}$. This demonstrates that $\mathrm{Al}$ can reduce the corrosion resistance of the solder. From Table 3, it is seen that the values of $\log |Z|$ and $\theta_{\max }$ decrease to $3139 \Omega \cdot \mathrm{cm}^{2}$ and $-73.72^{\circ}$, respectively for SAC105 $+0.1 \mathrm{Al}$ and they keep to decrease to $1456 \Omega \cdot \mathrm{cm}^{2}$ and $-62.94^{\circ}$ with the addition of $0.5 \mathrm{wt} . \% \mathrm{Al}$. At the highest concentration 


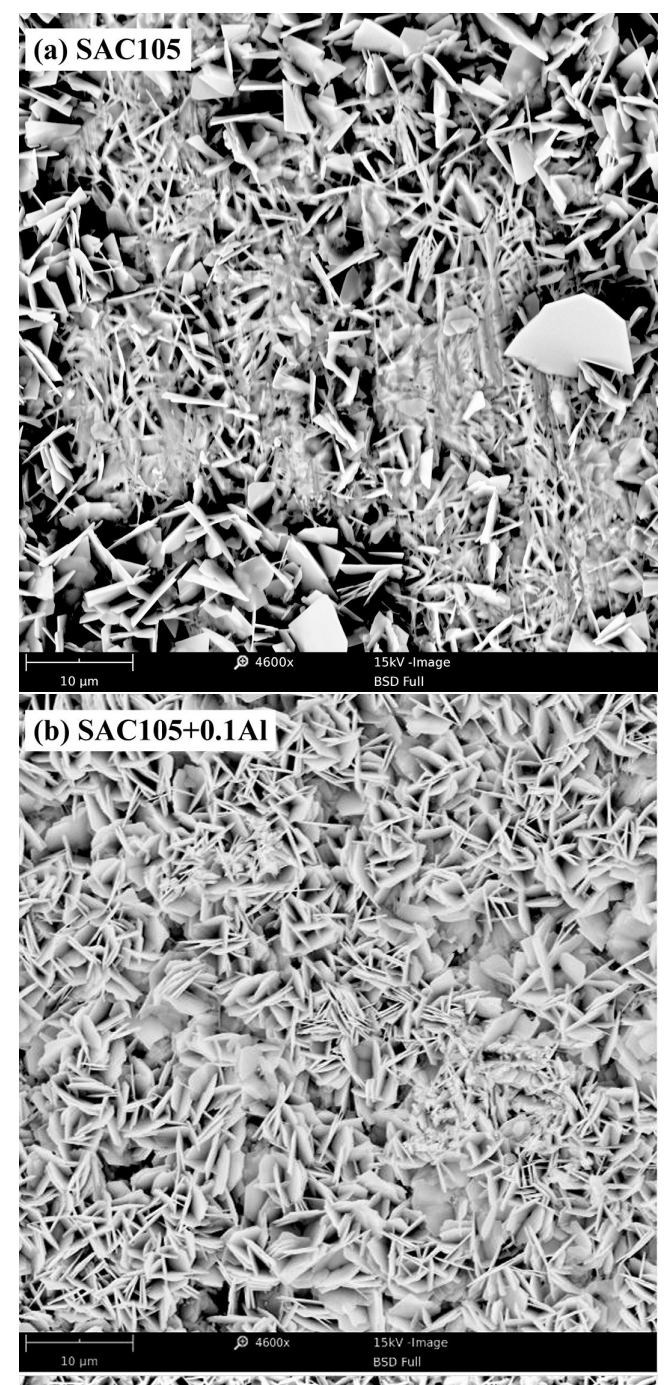

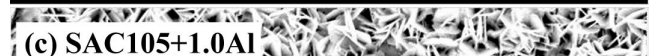

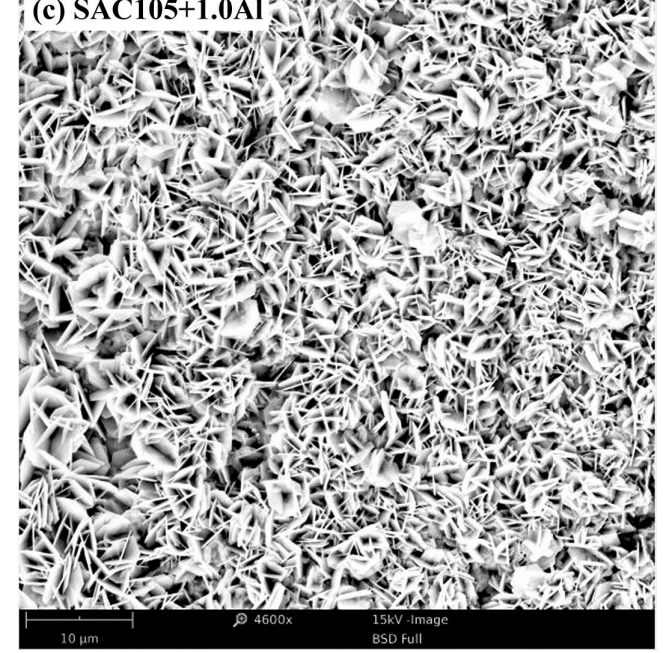

Fig. 2. SEM micrographs $(\times 4600)$ of SAC105 (a), $\mathrm{SAC} 105+0.1 \mathrm{Al}(\mathrm{b})$ and SAC105 + 1.0Al (c) solder alloys after polarization test.

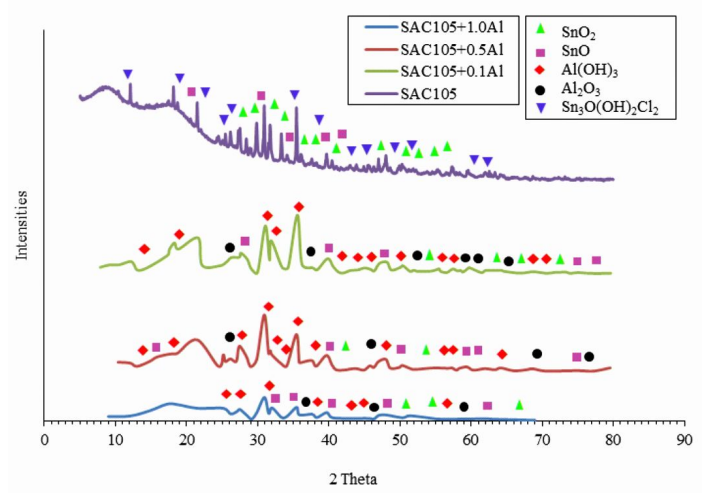

Fig. 3. X-ray diffraction scans after polarization for $\mathrm{SAC} 105, \mathrm{SAC} 105+0.1 \mathrm{Al}, \mathrm{SAC} 105+0.5 \mathrm{Al}$ and SAC105 + 1.0Al solder alloys in 3.5 wt. $\% \mathrm{NaCl}$ solution.

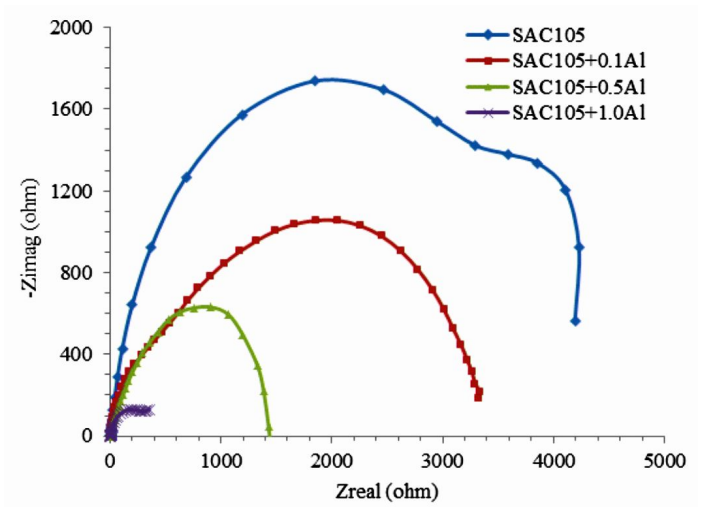

Fig. 4. Nyquist plot for SAC105, SAC105 + 0.1Al, $\mathrm{SAC} 105+0.5 \mathrm{Al}$ and SAC105 + 1.0Al solder alloys in 3.5 wt. $\% \mathrm{NaCl}$ solution.

of Al (1.0 wt.\%), SAC105 alloy exhibits the lowest $\log |Z|\left(719.7 \Omega \cdot \mathrm{cm}^{2}\right)$ and $\theta_{\max }\left(-61.89^{\circ}\right)$. It can be concluded that the addition of $\mathrm{Al}$ into the SAC105 solder causes a decrease in the corrosion resistance of the solder and SAC105 without Al addition exhibits the best corrosion resistance as compared to the other solders.

\section{Conclusions}

The following conclusions could be drawn from the present study

1. The corrosion current densities of $\mathrm{SAC} 105+0.1 \mathrm{Al}, \quad \mathrm{SAC} 105+0.5 \mathrm{Al}$ and SAC105 $+1.0 \mathrm{Al}$ solder alloys 
Table 3. Electrochemical impedance spectroscopy parameters for SAC105, SAC105 + 0.1Al, SAC105 + 0.5Al and SAC105 + 1.0Al solder alloys in $3.5 \mathrm{wt} . \% \mathrm{NaCl}$ solution.

\begin{tabular}{lcc}
\hline Solder alloys & $\log |\mathrm{Z}|\left[\Omega \cdot \mathrm{cm}^{2}\right]$ & $\theta_{\text {max. }}\left[{ }^{\circ}\right]$ \\
\hline \hline SAC105 & 4229.0 & -77.28 \\
SAC105 +0.1Al & 3139.0 & -73.72 \\
SAC105 + 0.5Al & 1456.0 & -62.94 \\
SAC105 + 1.0Al & 719.7 & -61.89 \\
\hline
\end{tabular}
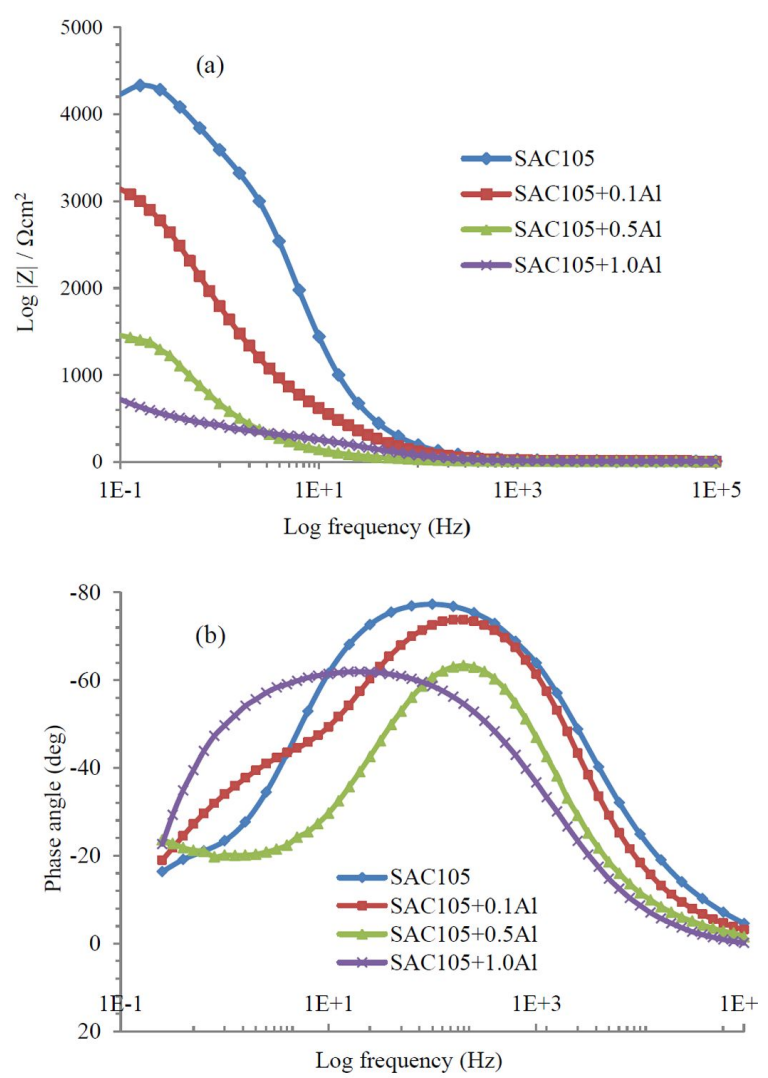

Fig. 5.5 (a) magnitude Bode plot and (b) phase angle Bode plot for SAC105, SAC105 + 0.1Al, $\mathrm{SAC} 105+0.5 \mathrm{Al}$ and SAC105 + 1.0Al solder alloys in $3.5 \mathrm{wt} . \% \mathrm{NaCl}$ solution.

are $0.526 \times 10^{-3}, 11.1 \times 10^{-3}$ and $11.6 \times 10^{-3} \mathrm{~mA} / \mathrm{cm}^{2}$, respectively. With the increase of aluminum concentration in SAC105 solder alloy, the corrosion current density increases and polarization resistance decreases. This corrosion behavior seems to be attributed to anodic dissolution of aluminum and $\mathrm{Sn}$ matrix. Therefore, it can be concluded that the addition of $\mathrm{Al}$ decreases the corrosion resistance of the SAC105 solder alloy.

2. The common corrosion products form $\mathrm{SAC} 105$ include $\mathrm{SnO}, \quad \mathrm{SnO}_{2}$ and $\mathrm{Sn}_{3} \mathrm{O}(\mathrm{OH})_{2} \mathrm{Cl}_{2}$. In our study, $\mathrm{Sn}_{3} \mathrm{O}(\mathrm{OH})_{2} \mathrm{Cl}_{2}$ was undetectable when $\mathrm{Al}$ was added into SAC105 alloy. Instead, $\mathrm{Al}(\mathrm{OH})_{3}$ and $\mathrm{Al}_{2} \mathrm{O}_{3}$ appeared to be formed on SAC105+0.1Al, SAC105+0.5Al and SAC105 + 1.0Al solder surfaces.

3. Electrochemical impedance spectroscopy measurements showed that SAC105 solder alloy had the best electrochemical corrosion resistance. As $\mathrm{Al}$ was added into SAC105 alloy, the loop diameter was decreased which indicates the increased corrosion rate. Therefore, corrosion resistance was reduced with the addition of Al. This observation permits to conclude that the SAC105 solder alloy without Al addition has the best corrosion resistance as compared to others alloys.

\section{Acknowledgements}

The authors would like to acknowledge this project; the HIR project No: UM.C/625/1/HIR/MOHE/ENG/26. Author also would like to acknowledge the financial support provided by University of Malaya project (RP013B-13AET).

\section{References}

[1] Mohanty U.S., Lin K.L., Appl. Surf. Sci., 252 (2006), 5907.

[2] Osorio W.R., Spinelli J.E., Afonso C.R.M., Peixoto L.C., Garcia A., Electrochim. Acta, 56 (2011), 8891.

[3] Leonardo R.G., Osorio W.R., Peixoto L.C., GARCIA A., Mater. Charact., 61 (2010), 212. 
[4] Mohanty U.S., Lin K.L., J. Electrochem. Soc., 153 (2006), B319.

[5] Raeder C.H., Felton L.E., Tanzi V.A., KnORR D.B., J. Electron. Mater., 23 (1994), 611.

[6] Tomlinson W.J., CollieR I., J. Mater.Sci., 22 (1987), 1835.

[7] Harada M., Satoh R., IEEE Trans. Compon., Hybrids, Manuf. Technol., 13 (1990), 736.

[8] MCCORMack M., Jin S., J. Electron. Mater, 23 (1994), 635.

[9] Sabri M.F.M., Dhafer A.S., Irfan A.B., Suhana M.S., ChE F.X., TADAShI A., Mater. Charact., 78 (2013), 129.

[10] Xu L., Pang J.H.L., Che F., J. Electron. Mater, 37 (2008), 880.

[11] You T., Kim Y., Kim J., LeE J., Jung B., Moon J., J. Electron. Mater., 38 (2009), 410.

[12] LiU W., LEE N.C., JOM, 59 (2007), 26.

[13] Huang B., Hwang H.S., Lee N.C., Proc. Electronic Components and Technology Conf. (IEEE), 2007, 184.

[14] Birzer C., Rakow B., Steiner R., Walter J., Proc. Electronics Packaging Technology Conf. (IEEE), 2005, 255.

[15] ZhaO X.J., Caers J.F.J.M., DE VRIES J.W.C., Kloosterman J., Wong E.H., Rajoo R., Proc. Electronics Packaging Technology Conf. (IEEE), 2006, 174.
[16] Kim D., Suh D., Millard T., Kim H., Kumar C., ZHU M., Xu Y., Proc. Electronic Components and Technology Conf. (IEEE), 2007, 1614.

[17] Suh D., Kim D. W., LiU P., Kim H., Weninger J.A., Kumar C.M., Prasad A., Grimsley B.W., TEJADA H.B., Mater. Sci. Eng., A, (2007), 595.

[18] Kittidacha W., Kanjanavikat A., VATTAANANIYOM K., Proc. Electronics Packaging Technology Conf. (IEEE), 2008, 1074.

[19] Kariya Y., Hossi T., Terashima S., Tanaka M., OtsuKa M., J. Electron. Mater., 33 (2004), 321.

[20] Wei C., LiU Y.C., Yu L.M., Chen H., WANG X., Microelectron. Reliab., 50 (2010), 1142.

[21] Dhafer A.S., SAbri M.F.M., Irfan A.B., Suhana M.S., Che F.X., J. Mater. Sci. Mater. El., 23 (2012), 1988.

[22] LEE Y.W., KiM I.H., KiM E.S., LEE J.H., MoON J.T., Proc. Electronics Packaging Technology Conf. (IEEE), 2010, 429.

[23] Stirrup B.N., Hampson N.A., Surf. Technol., 5 (1977), 429.

[24] Drogowska M., Menard H., Brossard L., J. Appl. Electrochem., 21 (1991), 84.

[25] Pistorius P.C., Burstein G.T., Corros. Sci., 38 (1994), 1525.

Received 2016-04-15 Accepted 2017-11-08 